\title{
Detection of immunoglobulin-G-binding proteins in Streptococcus suis
}

\author{
Bouchra Serhir, Robert Higgins, Bernadette Foiry and Mario Jacques* \\ Département de pathologie et microbiologie, Faculté de Médecine Vétérinaire, Université de Montréal, CP 5000, \\ Saint-Hyacinthe, Québec, Canada J2S 7 C6
}

(Received 15 June 1993; revised 19 August 1993; accepted 17 September 1993)

\begin{abstract}
This study was undertaken to search for the presence of immunoglobulin G (IgG)-binding proteins in Streptococcus suis, an important swine pathogen. Whole bacterial cells were incubated with human or pig IgG conjugated to gold particles and examined by transmission electron microscopy. Cells of some $S$. suis strains were labelled as were cells of the positive control strain, Staphylococcus aureus Cowan I. Binding of pig and human IgG to five different bacterial species of group D streptococci, to reference strains representing the 29 capsular types of $S$. suis, and to $12 S$. suis capsular type 2 strains was then examined using Western blotting. All strains interacted with pig and human IgG, although the binding profiles were slightly different. A $52 \mathrm{kDa}$ protein was observed in all capsular types of $S$. suis. This protein, absent in other group D streptococcal species, was observed in all capsular type 2 isolates originating from diseased or clinically healthy pigs, and was shown to bind human IgG-Fc fragments. The IgG-binding activity was also observed in the culture supernatant and was sensitive to proteolysis.
\end{abstract}

\section{Introduction}

Several bacterial species express surface proteins that interact with immunoglobulin (Ig) $\mathrm{G}$ molecules in nonimmune reactions. These binding proteins have been reported on staphylococci (Forsgren \& Sjöquist, 1966), streptococci of serological groups A, B, C, G, L and U (Kronvall, 1973; Chhatwal et al., 1985), and other microorganisms such as Haemophilus somnus, Clostridium perfringens and Mycoplasma salivarium (Lindahl \& Kronvall, 1988; Yarnall et al., 1988; Sawa et al., 1992).

Based on the non-immune reactivity of intact bacteria with various IgG species and subclasses, a functional classification was established and six different types of IgG-binding proteins were defined (Myhre \& Kronvall, 1981; Reis et al., 1988). The most extensively studied is type I, expressed by the majority of Staphylococcus aureus strains and designated protein A (Boyle, 1990), followed by type III, found on the surface of most human groups $C$ and $G$ streptococcal strains and commonly designated protein G (Björck \& Akerström, 1990). The type II, associated with group A streptococci, represents the most diverse and heterogeneous group of IgG-binding proteins (Reader et al., 1991). Type IV is found on certain bovine group $\mathrm{G}$ streptococci, and types

\footnotetext{
*Author for correspondence. Tel. +15147738521 ext. $348 ;$ fax +1 5147735633.
}

$\mathrm{V}$ and VI are found on different Streptococcus zooepidemicus strains (Myhre \& Kronvall, 1981).

The presence of immunoglobulin-binding proteins on the surface of different pathogens led to the suggestion that these molecules provide pathogens with the potential to evade or elude the host defences by interfering with opsonization, phagocytosis or complement consumption (Widders, 1990).

The presence of an IgG-binding activity has been reported on some human group D streptococci (Christensen \& Kronvall, 1974). Streptococcus suis, which also belongs to the Lancefield group $\mathrm{D}$, is a common cause of septicaemia, meningitis and other serious infections in pigs (Higgins \& Gottschalk, 1990). It has also been isolated from other animal species (Hommez et al., 1988; Higgins et al., 1990), as well as from humans (Arends \& Zanen, 1988; Trottier et al., 1991). Twenty-nine capsular types of $S$. suis have been described (Gottschalk et al., 1991). In many countries, capsular type 2 is considered as the most virulent and prevalent capsular type in diseased pigs (Higgins et al., 1992), but isolates belonging to this capsular type have also been found in nasal cavities of clinically healthy pigs (Brisebois et al., 1990). Little is known about the virulence factors involved in the pathogenesis of $S$. suis infections. It has been shown that surface components such as the capsular polysaccharides and some cell wall proteins as well as an extracellular protein could be associated with the virulence of $S$. suis 
capsular type 2 (Vecht et al., 1991; Gottschalk et al., 1992). The purpose of the present study was to search for the presence of IgG-binding proteins in S. suis.

\section{Methods}

Bacterial strains and growth conditions. Reference strains of S. suis capsular types 1 through 8 and $1 / 2$ were kindly supplied by Jorgen Henrichsen, Statens Seruminstitute, Copenhagen, Denmark. Reference strains of $S$. suis capsular types 9 through 28, Enterococcus faecalis (ATCC 19433), Enterococcus faecium (ATCC 2440), Streptococcus bovis (ATCC 9809), Streptococcus equinus (77-1020), Staphylococcus aureus Cowan I (ATCC 12598) and Staphylococcus epidermidis (ATCC 14990) were from our laboratory. Twelve S. suis capsular type 2 field strains originating from clinically healthy or diseased pigs and from different geographical areas were selected according to data obtained from studies based on restriction endonuclease fingerprinting and ribotyping (Beaudoin et al., 1992). A non-capsulated $S$. suis strain (92-2872), obtained from our laboratory, was also included in the study. All $S$. suis strains were identified with biochemical tests (Sanford \& Higgins, 1992), and capsular typing was performed using the coagglutination and the capsular reaction tests (Higgins \& Gottschalk, 1990). The Lancefield group $D$ antigen was detected using a coagglutination reagent (Phadebact; Pharmacia Diagnostic). Bacteria were grown on blood agar plates (trypticase soy agar containing $5 \%$, $\mathrm{v} / \mathrm{v}$, bovine blood; BBL) and in Todd-Hewitt broth (Difco) for $18-24 \mathrm{~h}$ at $37{ }^{\circ} \mathrm{C}$ in a $5 \% \mathrm{CO}_{2}$ atmosphere.

Electron microscopy. (i) Whole cell labelling. Colloidal gold particles $(15 \mathrm{~nm})$ were prepared by the sodium citrate method as described by Frens (1973). The optimal concentration of human or pig IgG (Sigma) needed to stabilize the colloidal gold solution was estimated by a salt floculation test (Bendayan, 1984). IgGs were then mixed with the colloidal gold, and these complexes were sedimented by ultracentrifugation at $60000 \mathrm{~g}$ for $40 \mathrm{~min}$. The pellet was resuspended in $0.01 \mathrm{M}$ phosphate-buffered saline (PBS; 0.01 M-potassium phosphate, $0.85 \%$ $\mathrm{NaCl}, \mathrm{pH} \mathrm{7.2;)} \mathrm{pH} 7.2$ and stored at $4{ }^{\circ} \mathrm{C}$. A drop of a bacterial suspension was placed on Formvar-coated grids for $1 \mathrm{~min}$. After blocking for $5 \mathrm{~min}$ with $1 \%(\mathrm{w} / \mathrm{v})$ bovine albumin, grids were placed on drops of colloidal gold particles conjugated to human or pig IgG for $30 \mathrm{~min}$. Grids were then rinsed with distilled water, and examined with an electron microscope (Philips 201) at an accelerating voltage of $60 \mathrm{kV}$.

(ii) Post-embedding labelling. Bacterial cells were fixed for $2 \mathrm{~h}$ at room temperature in $0.1 \mathrm{M}$-cacodylate buffer $\mathrm{pH} 7.2$ containing $1 \%$ $(\mathrm{v} / \mathrm{v})$ glutaraldehyde and $2 \%(\mathrm{v} / \mathrm{v})$ paraformaldehyde. Bacteria were then immobilized in $4 \%$ agar $(\mathrm{w} / \mathrm{v})$, washed five times in cacodylate buffer and placed in $30 \%$, then in $40 \%(\mathrm{v} / \mathrm{v})$ ethanol, both for $30 \mathrm{~min}$ at $4{ }^{\circ} \mathrm{C}$. The bacterial cells were then processed through the following ethanol dehydration series with $30 \mathrm{~min}$ incubation at $-20{ }^{\circ} \mathrm{C}: 50 \%$, $60 \%, 70 \%, 80 \%, 90 \%$ and $100 \%(\mathrm{v} / \mathrm{v})$ ethanol. The following embedding procedure also was done at $-20^{\circ} \mathrm{C}$. Bacteria were transferred to Lowicryl $\mathrm{K} 4 \mathrm{M}$ resin/ethanol $(1: 1, \mathrm{v} / \mathrm{v})$ for $60 \mathrm{~min}$. Further transfers included resin/ethanol (2:1) and pure resin, both for $60 \mathrm{~min}$. Infiltration was continued in pure resin overnight. Cells were transferred to pure resin in Beem capsules. Polymerization was done in a UVC1 Cryo chamber (Ted Pella Inc.) by illumination with a $360 \mathrm{~nm}$ UV light at $-35^{\circ} \mathrm{C}$ for $48 \mathrm{~h}$, and then at room temperature for a further $4 \mathrm{~d}$. Blocks, stored with desiccant at $4{ }^{\circ} \mathrm{C}$ until use, were sectioned. Thin sections were labelled with $\mathrm{IgG}-$ gold as described above, and were stained with uranyl acetate and lead citrate.

SDS-PAGE and Western blot analysis. SDS-PAGE was done by using the discontinuous buffer system according to Laemmli (1970), with a $4.5 \%(\mathrm{w} / \mathrm{v})$ polyacrylamide stacking gel and a $12.5 \%(\mathrm{w} / \mathrm{v})$ polyacrylamide running gel. Samples were mixed with solubilization buffer $(2 \%, \mathrm{w} / \mathrm{v}$, SDS, $10 \%, \mathrm{w} / \mathrm{v}$, glycerol, $5 \%, \mathrm{v} / \mathrm{v}, \beta$ mercaptoethanol, $0.025 \%$ bromophenol blue in $62.5 \mathrm{~mm}-\mathrm{Tris} / \mathrm{HCl}$, $\mathrm{pH} 6.8$ ) to a final concentration of $0.1 \mathrm{~g} \mathrm{ml}^{-1}$, and boiled for $10 \mathrm{~min}$. Low-molecular-mass markers and prestained low-molecular-mass markers obtained from Bio-Rad were used. Gels were run on a MiniProtean II vertical slab electrophoresis cell (Bio-Rad). Western blot analysis was done as described by Towbin et al. (1979) with some modifications. The separated proteins were transferred to a nitrocellulose membrane (Bio-Rad) which was then blocked with $2 \%(\mathrm{w} / \mathrm{v})$ skim milk in Tris-buffered saline (TBS; $10 \mathrm{~mm}$-Tris/HCl, $150 \mathrm{~mm}$ $\mathrm{NaCl}, \mathrm{pH} 7.4$ ) for $60 \mathrm{~min}$ at room temperature, and incubated with human or pig IgG at a concentration of $10 \mu \mathrm{g} \mathrm{ml}^{-1}$ in the blocking solution overnight at $4{ }^{\circ} \mathrm{C}$; control membranes were incubated overnight without $\mathrm{IgG}$. The membrane was washed four times in TBS containing $0.02 \%(\mathrm{v} / \mathrm{v})$ Tween 20 , then reacted with horseradishperoxidase-conjugated goat anti-human or anti-pig IgG (Jackson Immunoresearch Laboratories) also in blocking solution. After a subsequent washing, bands were developed by adding a solution of 4-chloro-1-naphthol. For the detection of human $\operatorname{IgG}(\mathrm{Fc})$-binding activity, the membrane was incubated with $10 \mu \mathrm{g} \mathrm{ml}^{-1}$ of peroxidaselabelled human Fc fragments (Jackson Immunoresearch Laboratories) for $2 \mathrm{~h}$ at room temperature, and was developed as described above.

Proteolytic treatment. Agar-grown bacteria were treated with proteinase $\mathrm{K}\left(1 \mathrm{mg} \mathrm{ml}^{-1}\right.$; Sigma) in $50 \mathrm{~mm}$-Tris $/ \mathrm{HCl}$, $\mathrm{pH} 8.0$, containing $1 \mathrm{mM}-\mathrm{CaCl}_{2}$; the mixture was incubated at $60^{\circ} \mathrm{C}$ for $60 \mathrm{~min}$. Treated bacterial cells were examined for their IgG-binding activity by electron microscopy.

Detection of IgG-binding proteins in culture supernatants. Bacteria, grown in liquid medium overnight at $37^{\circ} \mathrm{C}$ with agitation, were removed by centrifugation at $10000 \mathrm{~g}$ for $10 \mathrm{~min}$ and filtration through a $0.2 \mu \mathrm{m}$ membrane (Nalge Co.). The cell-free culture supernatant was concentrated 20-fold by ultrafiltration using a YM10 membrane (Amicon). The concentrated supernatants were subjected to SDSPAGE and Western blot analysis as described above.

\section{Results}

\section{Pig IgG-binding activity}

Colloidal gold particles $(15 \mathrm{~nm})$ were conjugated to pig $\mathrm{IgG}$, and these complexes were allowed to react with whole bacterial cells. The IgG-binding activity was examined by electron microscopy, and it was observed that the surface of the non-capsulated strain 92-2872 was labelled (Fig. 1a).

Approximately 70 gold particles (on average) were distributed uniformly on the cell surface. This labelling was similar to the one observed with the positive control, Staphylococcus aureus Cowan I (Fig. 1b). Labelling was absent or weak (less than 8 gold particles by cell) on the surface of capsulated strains of S. suis (Fig. 1c), similar to that observed with the negative control, Staphylococcus epidermidis (data not shown). The IgG-binding activity was also examined on thin sections of $S$. suis capsular type 2, and labelling of the cytoplasm and the cell wall region was observed (Fig. $1 d$ ).

Binding of pig IgG to five different species of group D streptococci, to the reference strains representing the 29 capsular types of $S$. suis, and to 12 S. suis capsular type 

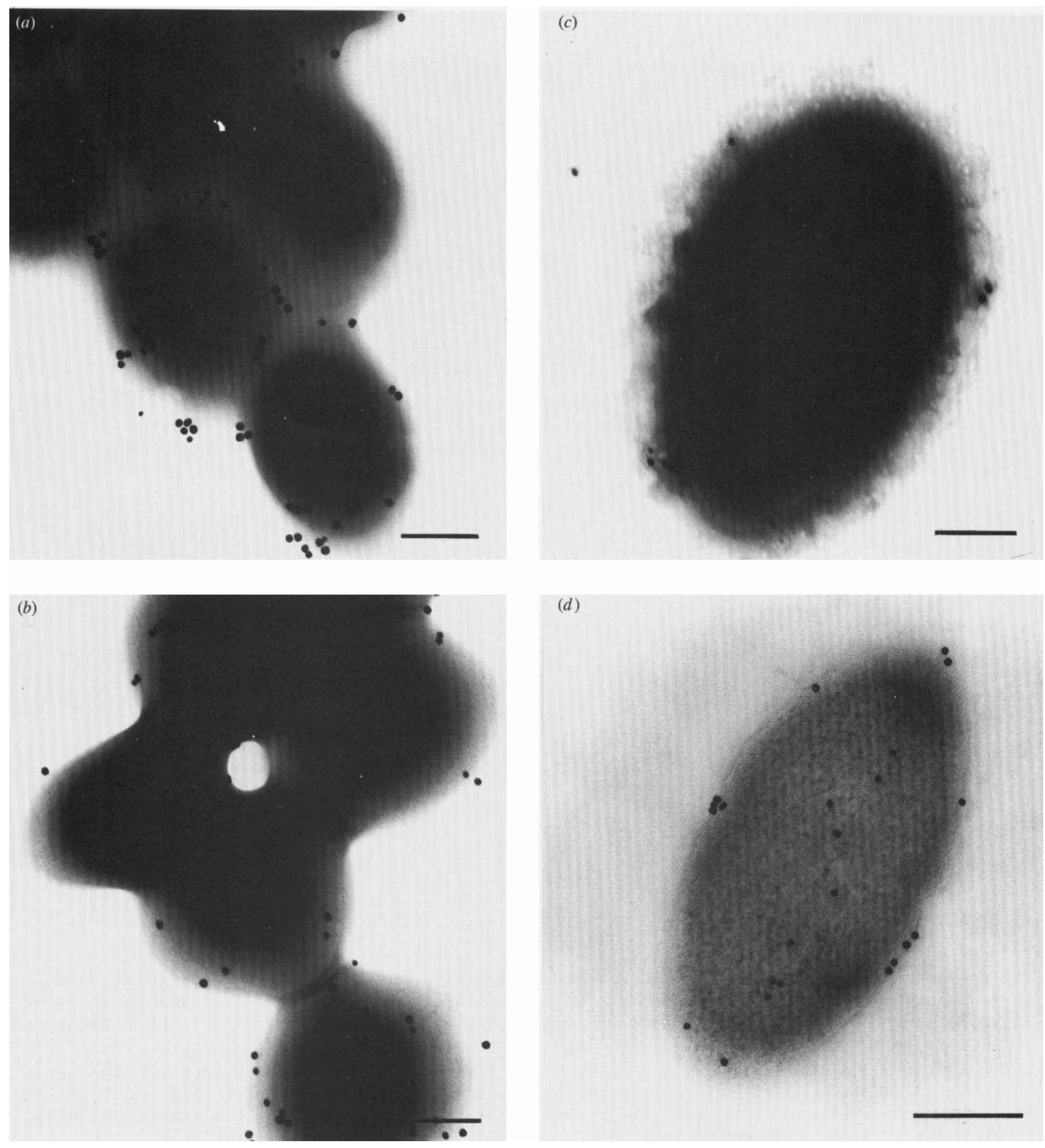

Fig. 1. Transmission electron micrographs of S. suis 92-2872 (a), Staphylococcus aureus Cowan I $(b)$ and $S$. suis capsular type $2(c)$ whole cells, as well as thin sections of $S$. suis S735 (d) labelled with pig IgG conjugated to gold particles (15 nm). Bars, $200 \mathrm{~nm}$.

2 strains was then examined using Western blotting. Negative (S. epidermidis) and positive (Staphylococcus aureus) bacterial controls were included in each test. All strains interacted with pig IgG. Analysis of five group D streptococcal species revealed the presence of distinct IgG-binding profiles (Fig. 2a). S. suis was represented by the reference strain of capsular type 2 (lane 3 ). Molecular masses of the major binding proteins varied between 52 and $80 \mathrm{kDa}$, and no common protein was observed between $S$. suis capsular type 2 and the other group D species, which were E. faecalis (lane 1), E. faecium (lane 2), S. equinus (lane 4) and S. bovis (lane 5). 


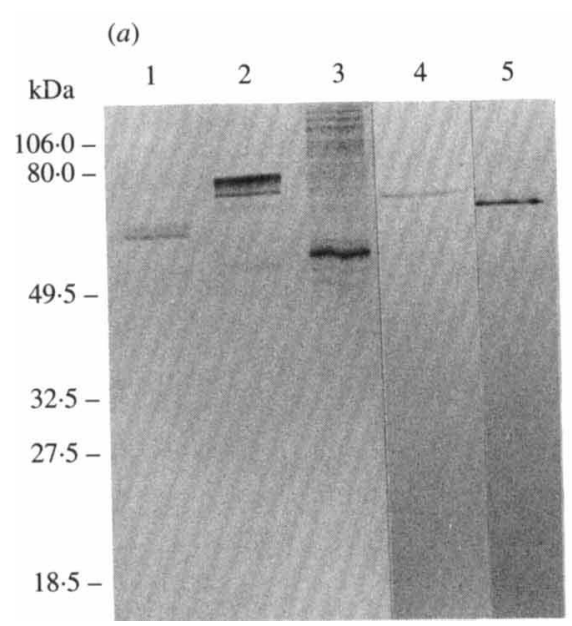

(b)
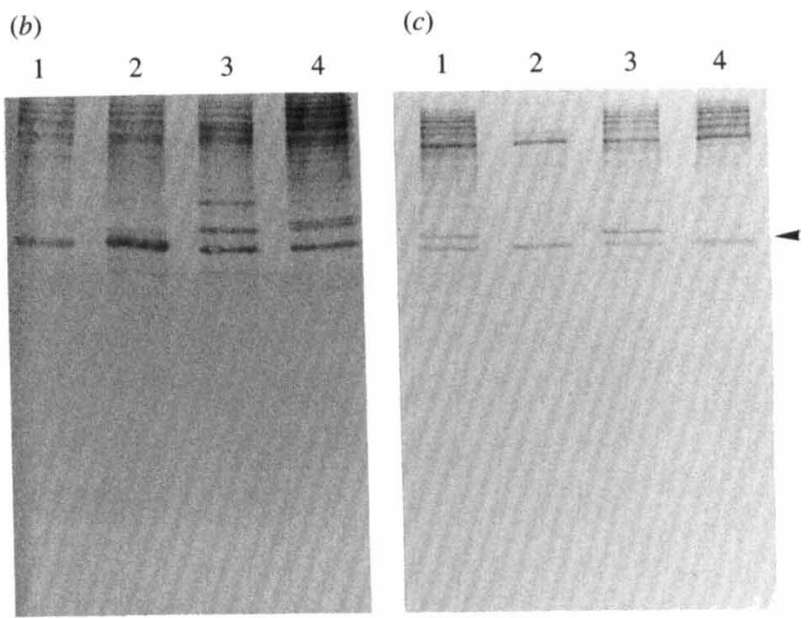

Fig. 2. Western blot of whole bacterial cells probed with pig IgG. (a) Lanes: 1, E. faecalis 19433; 2, E. faecium 2440; 3, S. suis capsular type $2 ; 4$, S. equinus 77-1020;5, S. bovis 9809 . (b) Lanes 1 to 4, reference strains of $S$. suis capsular types 7, 2, 3 and 16 respectively. (c) Lanes 1 to 4 , different field strains of $S$. suis capsular type 2. The arrowhead indicates the $52 \mathrm{kDa}$ binding protein. Molecular mass markers (in kilodaltons) are indicated on the left.

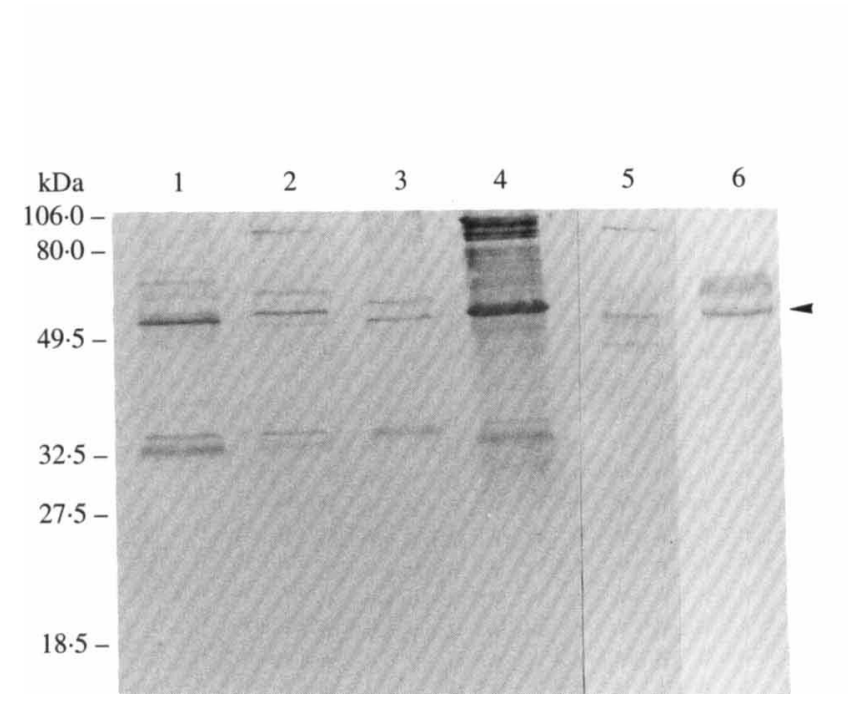

Fig. 3

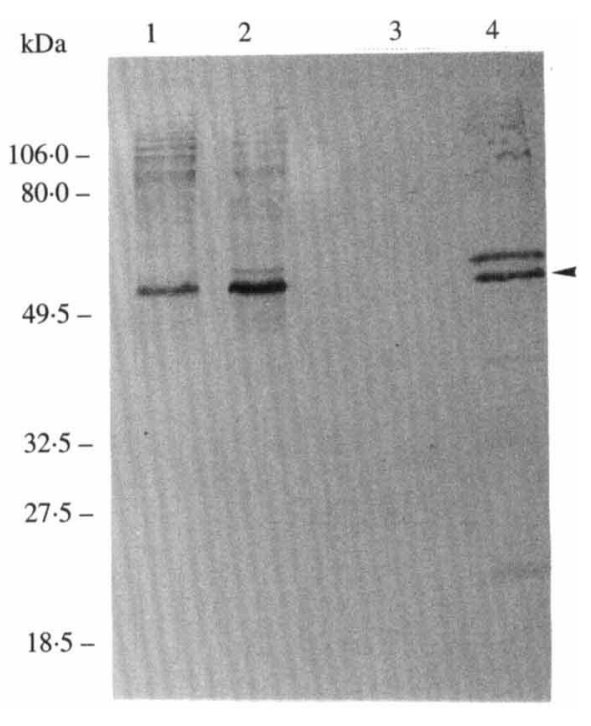

Fig. 4

Fig. 3. Western blot of whole bacterial cells of $S$. suis probed with human IgG. Lanes 1 to 4 , reference strains of capsular types 7, 3, 16 and 2 respectively; lanes 5 and 6, reference strains of $S$. suis capsular type 2 and $S$. suis 92-2872, respectively, probed with human $\mathrm{IgG}-\mathrm{Fc}$ fragments conjugated to peroxidase. The arrowhead indicates the $52 \mathrm{kDa}$ binding protein. Molecular mass markers (in kilodaltons) are indicated on the left.

Fig. 4. Western blot of whole bacterial cells of $S$. suis capsular type 2 grown on blood agar plates (lane 1) or in Todd-Hewitt broth (lane 2), of S. suis capsular type 2 Todd-Hewitt broth culture supernatant (lane 4), and of a control, non-inoculated Todd-Hewitt broth concentrated 20-fold (lane 3) probed with pig IgG. The arrowhead indicates the $52 \mathrm{kDa}$ binding protein. Molecular mass markers (in kilodaltons) are indicated on the left.

The 29 reference strains of $S$. suis capsular types were examined to determine whether these strains displayed IgG-binding activity, and had similar binding profiles. Molecular masses of the major IgG-binding proteins varied between 52 and $70 \mathrm{kDa}$; minor bands of higher molecular mass ( $>80 \mathrm{kDa}$ ) were also present (Fig. $2 b$ ). No characteristic profile was associated with strains from diseased pigs (e.g. capsular types $2,1 / 2,3,8$ ), or from clinically healthy pigs (e.g. capsular types 17, 18, 21). All 29 reference strains of $S$. suis presented a common protein with an approximate molecular mass of $52 \mathrm{kDa}$.

Twelve capsular type 2 isolates from clinically healthy pigs, or animals with septicaemia, pneumonia or meningitis, were analysed by Western blot. These capsular type 2 strains expressed a more homogeneous IgGbinding profile (Fig. $2 c$ ). No particular binding profile 
could be associated to strains from diseased (meningitis, lane 1 ; pneumonia, lane 2 ; septicaemia, lane 3 ) or healthy (lane 4) pigs. The common $52 \mathrm{kDa}$ protein, observed in all $S$. suis capsular types, was also present in all capsular type 2 strains tested.

\section{Human IgG-binding activity}

Using electron microscopy, the surface of the noncapsulated $S$. suis strain was labelled with human IgG-gold particles, and the density of the labelling was similar to the one observed previously with pig IgG-gold. Thin sections of $S$. suis capsular type 2 were also labelled with human IgG-gold, and labelling was observed on the cell wall and in the cytoplasm (data not shown). By Western blotting analysis, proteins reacting with pig IgG also bound human IgG. In addition, proteins in the 33 to $40 \mathrm{kDa}$ region were observed (Fig. 3, lanes 1 to 4). The non-capsulated $S$. suis strain $92-2872$ as well as the different capsular types reacted with human $\operatorname{IgG}(\mathrm{Fc})$ fragments using Western blotting; the proteins in the 33 to $40 \mathrm{kDa}$ region did not bind the Fc fragment (Fig. 3, lanes 5 and 6), but the $52 \mathrm{kDa}$ protein did. After treatment of $S$. suis cells with proteinase $\mathrm{K}$, no binding activity was observed by electron microscopy analysis; both human and pig IgG-binding activities were completely abolished.

\section{IgG-binding proteins in the culture supernatant}

IgG-binding activity was observed in $S$. suis culture supernatants (Fig. 4, lane 4). The binding profile was similar to that of whole bacterial cells grown on blood agar plates (lane 1) or in Todd-Hewitt broth (lane 2).

\section{Discussion}

The ability to bind IgG by a non-immune mechanism is a property shared by certain staphylococcal strains and streptococcal groups (Forsgren \& Sjöquist, 1966; Kronvall, 1973). This property has been reported once for some human group D streptococci (Christensen \& Kronvall, 1974). The results of this study demonstrate the presence of human and pig IgG-binding activities in five species of group D streptococci, particularly in the important swine pathogen $S$. suis. The binding was mediated by a proteineous molecule since activity was abolished following digestion with proteinase $\mathrm{K}$.

The five group D streptococcal species as well as all $S$. suis strains tested bound both pig and human IgG. A variation in the molecular mass of the different IgGbinding proteins was observed between the group $\mathrm{D}$ species. This heterogeneity was less pronounced among the 29 capsular types of $S$. suis, and even less within strains of the same capsular type. This is in agreement with previous studies which demonstrated variations in the molecular mass of Ig-binding proteins of groups B and C streptococci (Yarnall \& Widders, 1990). Studies, in group B streptococci, suggest that the $\beta$ antigen which binds the IgA Fc fragment is expressed as a lowmolecular-mass molecule, but can be processed to a higher molecular mass (Brady \& Boyle, 1990). These findings could explain the presence of multiple bands of molecular mass $>52 \mathrm{kDa}$ in $S$. suis. Field strains of S. suis capsular type 2 of different origins (pneumonia, meningitis, septicaemia or healthy animals) were genotypically characterized by fingerprinting and ribotyping (Beaudoin et al., 1992). Our results did not demonstrate any correlation between the IgG-binding profile of $S$. suis strains and their origin. Interestingly, a $52 \mathrm{kDa}$ protein was observed in all $S$. suis capsular types examined, and was characteristic of this species. Variation in the expression level of this protein was, however, noted among the different capsular types. This protein was also able to bind human $\mathrm{IgG}(\mathrm{Fc})$ fragments, which suggests that the $52 \mathrm{kDa}$ IgG-binding protein of $S$. suis is a Fc-receptor.

Like the majority of bacterial IgG-binding proteins (Yarnall et al., 1988), the S. suis proteins were associated with the cell surface, and also released in a soluble form during bacterial growth. Their presence, observed by electron microscopy, in the central region of the cell could be explained because they are synthesized in the cytoplasm, then carried to the cell surface. These proteins have an important role in virulence, perhaps by favouring bacterial persistence in vivo (Widders, 1990).

It is quite possible that the capsule layer of $S$. suis (Jacques et al., 1990) masked the binding proteins because, using electron microscopy, they were best observed on the surface of the non-capsulated S. suis strain but could be detected on sections of capsulated strains. This might explain why Lämmler et al. (1986) did not observe any IgG-binding activity on the surface of cells from six different group D streptococcal cultures.

This study has shown that group D streptococci exhibit pig and human IgG-binding activities, and that a $52 \mathrm{kDa}$ IgG-binding protein is present in all $S$. suis strains examined. This protein may therefore represent a common molecular marker for the rapid identification of $S$. suis. Further studies will be needed to determine the role of these IgG-binding proteins in $S$. suis pathogenesis.

We thank Dr Marcelo Gottschalk for reviewing the manuscript.

\section{References}

Arends, J. P. \& Zanen, H. C. (1988). Meningitis caused by Streptococcus suis in humans. Review of Infectious Diseases 10, 131-137. 
Beaudoin, M., Harel, J., Higgins, R., Gottschalk, M., Frenette, M. \& MacInNES, J. I. (1992). Molecular analysis of isolates of Streptococcus suis capsular type 2 by restriction-endonucleasedigested DNA separated on SDS-PAGE and by hybridization with an rDNA probe. Journal of General Microbiology 138, 2639-2645.

Bendayan, M. (1984). Protein A-gold electron microscopic immunochemistry: methods, applications, and limitations. Journal of Electron Microscopy Technique 1, 243-270.

BJÖRCK, L. \& AKERSTRÖM. (1990). Streptococcal protein G. In Bacterial Immunoglobulin Binding Proteins, vol. 1, pp. 113-126. Edited by M. D. P. Boyle. San Diego: Academic Press.

BoYLE, M. D. P. (1990). The type I bacterial immunoglobulin-binding protein: staphylococcal protein A. In Bacterial Immunoglobulin Binding Proteins, vol. 1, pp. 17-28. Edited by M. D. P. Boyle. San Diego: Academic Press.

Brady, L. J. \& Boyle, M. D. P. (1990). Immunoglobulin A Fc-binding proteins associated with group B streptococci. In Bacterial Immunoglobulin Binding Proteins, vol. 1, pp. 201-224. Edited by M. D. P. Boyle. San Diego: Academic Press.

Brisebois, L. M., Charlebois, R., Higgins, R. \& Nadeau, M. (1990). Prevalence of Streptococcus suis in four to eight week old clinically healthy piglets. Canadian Journal of Veterinary Research 54, 174-177.

ChHatwal, G. S., LäMmLer, Ch. \& Blobel, H. (1985). Interactions of plasma proteins with group A, B, C, and G streptococci. Zentralblatt für Bakteriologie und Hygiene 259, 219-227.

Christensen, P. \& Kronvall, G. (1974). Capacity of group A, B, C, $\mathrm{D}$, and $\mathrm{G}$ streptococci to agglutinate sensitized sheep red cells. Acta Pathologica et Microbiologica Scandinavica 82, 19-24.

ForsGren, A. \& SJöQuist, J. (1966). "Protein A" from Staphylococcus aureus. I. Pseudo-immune reaction with human $\delta$-globulin. Journal of Immunology 97, 822-827.

FRENS, G. (1973). Controlled nucleation for the regulation of the particle in size in monodisperse gold suspension. Nature, London 241, 20-22.

Gottschalk, M., Higgins, R., Jacques, M., Beaudoin, M. \& HeNrichsen, J. (1991). Characterization of six new capsular types (23-28) of Streptococcus suis. Journal of Clinical Microbiology 29, 2590-2594.

Gottschalk, M., Higgins, R., Jacques, M. \& Dubreuil, D. (1992). Production and characterization of two Streptococcus suis capsular type 2 mutants. Veterinary Microbiology 30, 59-71.

Higgins, R. \& GotTschalk, M. (1990). An update on Streptococcus suis identification. Journal of Veterinary Diagnostic Investigation 2 , 249-252.

Higgins, R., Gottschalk, M., Beaudoin, M. \& Rawluk, S. A. (1992). Distribution of Streptococcus suis capsular types in Quebec and western Canada. Canadian Veterinary Journal 33, 27-30.

Higgins, R., Gottschalk, M., Fecteau, G., Sauvageau, R., De GUISE, S. \& DU TREMblay, D. (1990). Isolation of Streptococcus suis from cattle. Canadian Veterinary Journal 31, 529.

Hommez, J., Wullepit, J. \& Cassimon, P. (1988). Streptococcus suis and other streptococcal species as a cause of extramammary infections in ruminants. Veterinary Record 123, 626-627.
JaCQues, M., GotTschalk, M., Folry, B. \& Higgins, R. (1990). Ultrastructural study of surface components of Streptococcus suis. Journal of Bacteriology 172, 2833-2838.

Kronvall, G. (1973). A surface component in group A, C, and G streptococci with nonimmune reactivity for immunoglobulin $\mathrm{G}$. Journal of Immunology 111, 1401-1406.

LaEMmLI, U. K. (1970). Cleavage of structural proteins during the assembly of the head of bacteriophage T4. Nature, London 227, 680-685.

Lämmler, C., Schaufub, P., Goretzki, K. \& Blobel, H. (1986) Screening for bacterial Fc-receptor activity on nitrocellulose membranes. Journal of Immunological Methods 90, 47-50.

Lindahl, G. \& Kronvall, G. (1988). Non-immune binding of IgG to Clostridium perfringens. Preferential binding of IgM and aggregated IgG. Journal of Immunology 140, 1223-1227.

MYHrE, E. B. \& KronvalL, G. (1981). Immunoglobulin specifications of defined types of streptococcal Ig receptors. In Basic Concepts of Streptococci and Streptococcal Diseases. Edited by S. E. Holm \& P. Christensen. Chertsey, Surrey: Reedbooks Ltd.

Reader, R. A., Faulmann, E. L. \& Boyle, M. D. P. (1991). Evidence for functional heterogeneity in IgG Fc-binding proteins associated with group A streptococci. Journal of Immunology 146, 1247-1253.

Reis, K. J., Siden, J. \& Boyle, M. D. P. (1988). Selective colony blotting to expand bacterial surface receptors: applications to receptors for rat immunoglobulins. Biotechniques 6, 130-136.

SANFORD, S. E. \& Higgins, R. (1992). Streptococcal Diseases. In Diseases of Swine, pp. 588-598. Edited by A. D. Leman, B. E. Straw, W. L. Mengeling, S. D'allaire \& D. J. Taylor. Ames, Iowa: Iowa State University Press.

Sawa, Y., Watanabe, T. \& Shibata, K. (1992). Immunoglobulin G Fc fragment-binding proteins in Mycoplasma salivarium cells. Microbiology and Immunology 36, 655-659.

Towbin, H., Staehelin, T. \& Gordon, J. (1979). Electrophoretic transfer of proteins from polyacrylamide gels to nitrocellulose sheets: procedure and some applications. Proceedings of the National Academy of Sciences of the United States of America 76, 4350-4353.

Trottier, S., Higgins, R., Brochu, G. \& Gottschalk, M. (1991). A case of human endocarditis due to Streptococcus suis in North America. Review of Infectious Diseases 13, 1251-1252.

Vecht, U., Wisselink, H. J., Jellema, M. L. \& Smith, H. E. (1991) Identification of two proteins associated with virulence of Streptococcus suis type 2. Infection and Immunity 59, 3156-3162.

WIDDERS, P. R. (1990). Fc receptors and the pathogenesis of bacterial infections in animals. In Bacterial Immunoglobulin Binding Proteins, vol. 1, pp. 375-396. Edited by M. D. P. Boyle. San Diego: Academic Press.

Yarnall, M. \& Widders, P. R. (1990). Type V Fc receptor from Streptococcus zooepidemicus. In Bacterial Immunoglobulin Binding Proteins, vol. 1, pp. 155-164. Edited by M. D. P. Boyle. San Diego: Academic Press.

Yarnall, M., Widders, P. R. \& CorbeiL, L. B. (1988). Isolation and characterization of $\mathrm{Fc}$ receptors from Haemophilus somnus. Scandinavian Journal of Immunology 28, 129-137. 